\title{
The Kongsfjorden Channel System offshore NW Svalbard: downslope sedimentary processes in a contour-current-dominated setting
}

\author{
Matthias Forwick $^{1} \cdot$ Jan Sverre Laberg $^{1} \cdot$ H. Christian Hass ${ }^{2} \cdot$ Giacomo Osti $^{3}$
}

Received: 1 September 2015 / Accepted: 20 October 2015/Published online: 23 November 2015

(C) Springer-Verlag Berlin Heidelberg 2015

\begin{abstract}
Submarine channel systems on and off glaciated continental margins can be up to hundreds of kilometres long, tens of kilometres wide and hundreds of metres deep. They result from repeated erosion and various downslope processes predominantly during glacial periods and can, therefore, provide valuable tools for the reconstruction of past ice-sheet dynamics. The Kongsfjorden Channel System (KCS) on the continental slope off northwest Svalbard provides evidence that downslope sedimentary processes are locally more dominant than regional along-slope sedimentation. It is a relatively short channel system $(\sim 120 \mathrm{~km})$ that occurs at a large range of water depths $(\sim 250-4000 \mathrm{~m})$ with slope gradients varying between $0^{\circ}$ and $20^{\circ}$. Multiple gullies on the Kongsfjorden Trough Mouth Fan merge to small channels that further merge to a main channel. The overall location of the channel system is controlled by variations in slope gradients and the ambient regional bathymetry. The widest and deepest incisions occur in areas of the steepest slope gradients. The KCS has probably been active since $\sim 1 \mathrm{Ma}$ when glacial activity on Svalbard increased and grounded ice expanded to the shelf break off Kongsfjorden
\end{abstract}

Matthias Forwick

Matthias.Forwick@uit.no

1 Department of Geology, University of Troms $\varnothing-$ The Arctic University of Norway, P.O. Box 6050, 9037 Langnes, Troms $\emptyset$, Norway

2 Wadden Sea Research Station, Alfred Wegener Institute for Polar and Marine Research, Hafenstrasse 43, 25992 List, Germany

3 Department of Geology, Centre of Arctic Gas Hydrate, Environment and Climate (CAGE), University of Troms $\varnothing-$ The Arctic University of Norway, P.O. Box 6050, 9037 Langnes, Tromsø, Norway repeatedly. Activity within the system was probably highest during glacials. However, reduced activity presumably took place also during interglacials.

Keywords Kongsfjorden Channel System · Svalbard · Continental slope · Contourite drifts · Glaciated continental margin

\section{Introduction}

The slopes of glaciated continental margins allow the study of a variety of sedimentary processes related to along-slope and downslope sedimentation (e.g. [66, 71]). Contourite drifts along the margins and within the adjacent deep sea suggest that bottom currents flowing parallel to the slopes can dominate the long-term sedimentation at local to regional scales (e.g. [7, 21, 23, 33, 36, 56, 57]). However, gullies, channels and canyons provide evidence of repeated and focused downslope processes leading to erosion and slope incision over time. Gullies are relatively small, confined channels, typically in the order of tens of metres deep (e.g. [19], and references therein). They are suggested to be the first erosional features forming on steeply dipping slopes in both terrestrial and marine settings [5, 34]. The formation mechanisms of submarine gullies remain poorly constrained. It has been suggested that they can form from a variety of mechanisms including small-scale mass wasting or erosion by cascading dense water masses during glaciations (e.g. [6, 19, 34, 72]). Submarine channel-levee systems can have vertical reliefs of up to several hundreds of metres and lengths of several hundreds of kilometres (e.g. [64, 65]). Channels form probably also due to downslope flow of dense water rejected from brine formation, as well as turbidity flows beyond the mouths of 


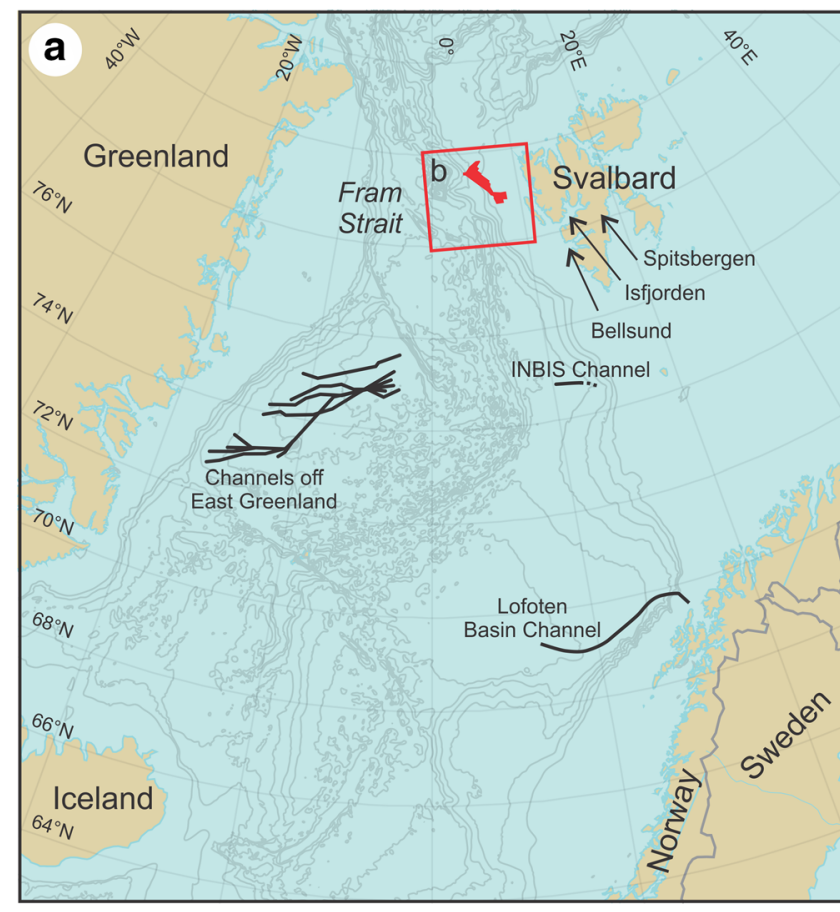

Fig. 1 Location of the study area. a Overview map of the Nordic Seas and approximate locations of channel systems off East Greenland, the Lofoten Basin Channel, the INBIS Channel, as well

glacial troughs, when grounded ice extends to the shelf break during full glacials (e.g. [8, 43, 48, 71]). The largest canyons are up to $2.6 \mathrm{~km}$ deep and $100 \mathrm{~km}$ wide [46]. Multiple factors contribute to the formation of canyons, in particular mass wasting [63], but also tectonic activity (e.g. [42]). Canyon formation can originate at both the lower and upper slopes (see [59], and references therein).

Multiple studies have been performed on channel systems on glaciated continental margins extending from the shelf break to abyssal plains (e.g. [29, 37, 43, 44, 48, 58, $71,73])$. In this study, we present swath bathymetry and subbottom profiler data from a channel system on the continental slope off NW Svalbard. The study area is located in a setting dominated by contourite-drift deposition on a narrow continental slope with a large variety of slope gradients, terminating in a mid-ocean spreading zone. We discuss parameters influencing the location and shape, as well as processes maintaining the system. Furthermore, we compare our results with studies of other channel systems to discuss factors controlling the location, origin and maintenance of high-latitude channel systems.

\section{Physiography}

The study area is located in the eastern Fram Strait, on the continental slope off NW Spitsbergen the largest island of the Svalbard archipelago $\left(\sim 78^{\circ} 50-79^{\circ} 50^{\prime} \mathrm{N} ; \sim 4^{\circ}-9^{\circ} \mathrm{E}\right)$

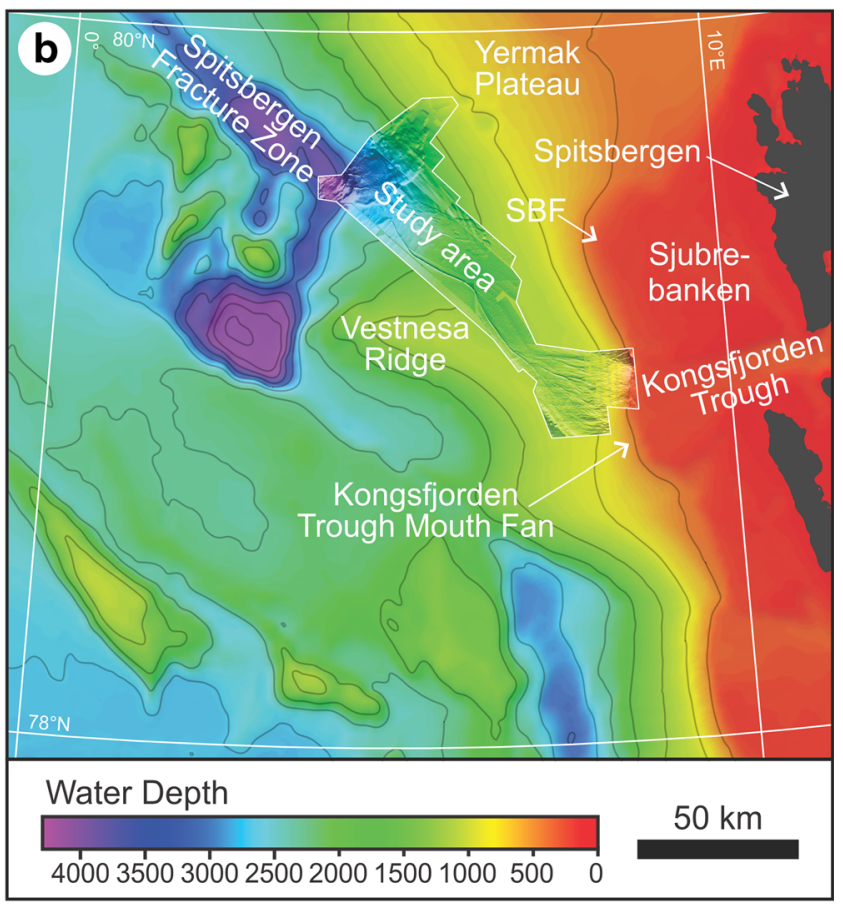

as the study area (for details and references, see Table 1). b Regional setting of the study area. SBF Sjubrebanken Fan

(Fig. 1). Its $\mathrm{N}-\mathrm{S}$ and $\mathrm{E}-\mathrm{W}$ extents are 120 and $90 \mathrm{~km}$, respectively. Water depths vary between $\sim 220 \mathrm{~m}$ on the outermost continental shelf and $\sim 4200 \mathrm{~m}$ in the Spitsbergen Fracture Zone (SFZ). Furthermore, its southernmost reaches cover parts of the northern slope of the Vestnesa Ridge.

The Fram Strait is the only deep-water connection between the Arctic Ocean and the world's oceans. Its opening started during late Oligocene to early Miocene [12, 67]. Ventilated circulation between the Arctic and Atlantic Oceans commenced around 18.2 Ma (millions of years before the present) and exceeded $2000 \mathrm{~m}$ water depth since 13.7 Ma [25]. The present-day large-scale hydrography in the Fram Strait is characterised by the northward flowing West Spitsbergen Current (WSC) and the southward flowing East Greenland Current (EGC) on the eastern and western sides of the strait, respectively. However, a general weak southward flow of deep-water masses, as well as the occurrence of gigantic meanders or eddies and the formation of the Return Atlantic Current, causes a more complex hydrography in the central parts of the Fram Strait (RAC; e.g. $[13,20,62])$. A continuous northward flow of water occurs in the study area east of $5^{\circ} \mathrm{E}$ [4]. Bottom-current velocities exceed $10 \mathrm{~cm} / \mathrm{s}$ shallower than $800 \mathrm{~m}$. They decrease from 10 to $0 \mathrm{~cm} / \mathrm{s}$ deeper than $800 \mathrm{~m}$. West of $5^{\circ}$ $\mathrm{E}$, bottom currents move southward with velocities of less than $5 \mathrm{~cm} / \mathrm{s}$ [4]. 
Contourite-drift deposition dominated the overall sedimentary environment in the eastern Fram Strait since at least $11 \mathrm{Ma}$ and numerous sediment drifts have been identified on the continental slope off western Svalbard, mainly at water depths exceeding $1200 \mathrm{~m} \mathrm{[7,} \mathrm{21,} \mathrm{23,} \mathrm{24,}$ $41,57,61]$. However, multiple escarpments north of the study area provide evidence of repeated downslope sediment transport ([10, 50]).

Lithological investigations reveal that the sedimentary environment during the past c. 30,000 years has been dominated by deposition from suspension settling, current modification and ice rafting (e.g. [22, 26]). However, generally coarser sediments, interpreted as mass-transport deposits, accumulated regionally between c. 24,000 and 23,300 cal. years BP, when grounded ice expanded to the shelf break [26].

The shallowest parts of the study area include the northern parts of the Kongsfjorden Trough Mouth Fan (TMF), a protrusion of the continental shelf off NW Spitsbergen (Fig. 1). This fan formed during multiple glaciations when fast-flowing ice streams, draining ice sheets covering the Svalbard archipelago, reached the shelf break repeatedly, delivering substantial amounts of sediment that failed and led to the formation and deposition of glacigenic debris flows (e.g. $[41,61,70])$. Furthermore, the study area includes the continental slope off Sjubrebanken, an area that was affected by ice streams prior to $\sim 1.5 \mathrm{Ma}$, but not or only slightly affected by fast-flowing grounded ice during the last glacials ([39, 41, 51, 61]; Fig. 1). At least 54 gullies intersect the shallowest parts of the study area [19].

The Vestnesa Ridge, a major geomorphological obstacle immediately south of the study area (Fig. 1), has a major influence on the location of the Kongsfjorden Channel System (see below). It is composed of a more than 2-kmthick sediment sequence mainly dominated by contourite drifts (e.g. [7, 23]). However, the upper part of the sediment column on the eastern Vestnesa Ridge is composed of prograding sequences reflecting enhanced sediment supply from Svalbard during glaciations [7].

Vogt et al. [68] presented the location of a section of the 'Kongsfjorden Canyon' immediately north of the Vestnesa Ridge for the first time. Hustoft et al. [24] showed parts of the same system that they named 'Kongsfjorden Channel'. However, we use the term 'Kongsfjorden Channel System' (KCS), because features shown by the authors mentioned above are part of a system, rather than a single channel or a canyon.

\section{Materials and methods}

Swath bathymetry and penetration echo sounder data (chirp) provide the basis for this study. The data were collected during cruises of R/V Jan Mayen (now R/V Helmer Hanssen) in the autumns of 2008, 2009 and 2010 [15-17].

The swath bathymetry data were collected with a hullmounted Kongsberg Maritime EM 300 multibeam echo sounder (135 beams, $30 \mathrm{kHz}$ ). Sound-velocity profiles for calibrating the instrument were obtained from CTD (conductivity-temperature-depth) casts performed prior to data acquisition. Data processing was performed using the software Neptune. However, up to 2.5-4-m-high waves during data acquisition resulted in partly limited data quality. The data are presented at a grid size of $25 \mathrm{~m} \times 25 \mathrm{~m}$ and a vertical exaggeration factor of 6 using Fledermaus.

The penetration echo sounder data were acquired in 2008 and 2009 with a hull-mounted EdgeTech 3300-HM subbottom profiler (chirp; $4 * 4$ array configuration; pulse mode: $1.5-9 \mathrm{kHz}, 40 \mathrm{~ms}$ ). A p-wave velocity of $1500 \mathrm{~m} / \mathrm{s}$ was applied for depths calculations.

\section{Results and interpretations}

\section{Overall bathymetry}

Repeated changes in slope gradients characterise the largescale bathymetry in the study area (Fig. 2). The slope gradient below the shelf break off Sjubrebanken $(\sim 250 \mathrm{~m})$ and the Kongsfjorden Trough $(\sim 290 \mathrm{~m})$ is up to $20^{\circ}$ and $12^{\circ}$, respectively. It decreases to $10^{\circ}-5^{\circ}$ between 400 and $\sim 650 \mathrm{~m}$, to $<2^{\circ}$ at $\sim 1100 \mathrm{~m}$ and towards $0^{\circ}$ around $1500 \mathrm{~m}$. Between $\sim 1700$ and $2400 \mathrm{~m}$, it increases to $2^{\circ}-$
Fig. 2 Downslope profile from the study area showing changes in slope gradients versus water depth. For location, see Fig. 3a

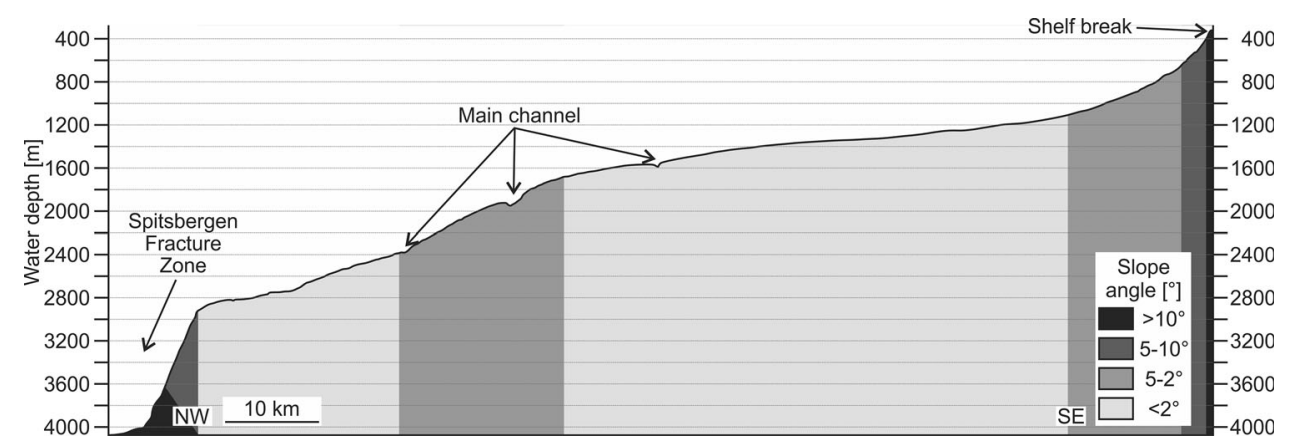


$4^{\circ}$, before decreasing again to $<2^{\circ}$ between $\sim 2400$ and $2900 \mathrm{~m}$. Below $2900 \mathrm{~m}$, at the transition into the SFZ, the slope gradient increases to predominantly $5^{\circ}-20^{\circ}$.

Numerous linear to slightly curved, northward dipping elongated mounds give the seafloor a wavy appearance between $\sim 1400$ and $3000 \mathrm{~m}$ water depth (Figs. 3, 4e, 5a). These mounds are typically $<10 \mathrm{~km}$ long, but can occasionally reach $20 \mathrm{~km}$ length. They are mostly between 1.5 and $2.5 \mathrm{~km}$ wide. Their maximum relief is $20 \mathrm{~m}$.

We interpret these sediment waves as plastered mounded contourite drifts (after [14]) that formed from the northward flow of bottom currents along the eastern slope of the Fram Strait. Similar drifts have been described immediately north of the study area [61], as well as from other places along the continental slope off west Svalbard, e.g. the SE Vestnesa Ridge (1226 m water depth; [23]), the SW Vestnesa Ridge (1500-2500 m water depth; [24]), the western slope of the Yermak Plateau [21], as well as off Isfjorden and Bellsund (1200-800 m water depth; [57]; for locations, see Fig. 1).

An approximately 20-m-high, approximately $2700-\mathrm{m}-$ long, N-S-oriented 'bathymetric step' occurs at $\sim 450 \mathrm{~m}$ off Sjubrebanken (Figs. 3, 4a). It is interpreted to be the headwall of a slab failure (compare with, e.g. [3]). Several straight to slightly curved incisions occur on the northernmost parts of the Kongsfjorden TMF and off Sjubrebanken, i.e. on the steepest part of the upper continental slope (Figs. 3, 4a). They are maximum $3000 \mathrm{~m}$ long, typically $200-500 \mathrm{~m}$ wide and maximum $40 \mathrm{~m}$ deep. Their upper limits either terminate some tens of metres below the shelf break or cut back into the shelf. Two of these incisions cut through the headwall of the slab failure. Parallel ridges/raised rims on their sides occur occasionally. Up to 5-m-high depositional features can be observed rarely at the lower ends of these incisions. However, some incisions appear to merge into small channels (see next paragraph). We suggest that these features reflect smallscale retrogressive mass wasting on these steep intervals of the continental slope. Multiple slide scars resulting from large-scale mass wasting occur below $1300-1400 \mathrm{~m}$ in the northern part of the study area (Figs. 3, 4e, 5; for details, see $[10,50]$.

\section{Gullies and small channels}

Multiple incisions originate at the shelf break or slightly below on the continental slope off the northern Kongsfjorden Trough (Figs. 3, 4a, 5). They belong to a dendritic network of incisions that expands at least $25 \mathrm{~km}$ in N-S direction and $\sim 35 \mathrm{~km}$ in $\mathrm{E}-\mathrm{W}$ direction. These $\mathrm{v}$-shaped, straight to sinuous incisions are up to $5 \mathrm{~m}$ deep, typically less than $200 \mathrm{~m}$ wide and often only partially visible due to the irregular surrounding relief and the partly limited data quality. However, below $1000 \mathrm{~m}$, maximum 5-m-deep and typically 200-500-m-wide incisions are visible (Figs. 3, $4 \mathrm{~b}, 5)$. These merge to a single, major incision at $1400 \mathrm{~m}$ water depth. The smallest incisions are interpreted to be gullies, whereas the larger ones are small channels (compare with $[19,71])$. The small channels located in the subhorizontal interval between $\sim 1150$ and $1400 \mathrm{~m}$ are the incisions with the highest sinuosity of the entire channel system.

\section{Main channel}

One major incision is approximately $60 \mathrm{~km}$ long and extends from the lowermost merging point of the smaller channels at $1400 \mathrm{~m}$ water depth to approximately $4000 \mathrm{~m}$ (Figs. 3, 4, 5, 6). It 'enters' the slide scars described by Osti et al. [50] at $2850 \mathrm{~m}$ water depth and 'exits' these again at $\sim 3100 \mathrm{~m}$ to continue into the SFZ. This incision is defined as the main channel of the KCS.

The main channel is largest between $\sim 1530$ and $2300 \mathrm{~m}$ water depth, i.e. in an area of relatively steep slope gradient (compare Figs. 2, 3, 5). There, it reaches a maximum width of $500 \mathrm{~m}$ and a depth of up to $80 \mathrm{~m}$. Maximum channel width and depth decrease to 400 and $20 \mathrm{~m}$, respectively, between 2300 and $2680 \mathrm{~m}$ water depths. They decrease further to maximum 200 and $5 \mathrm{~m}$ between 2680 and $2960 \mathrm{~m}$. At these water depth, the channel occasionally disappears. The reduction in channel size coincides with a decrease in slope gradient. Channel size increases again below $2960 \mathrm{~m}$ (i.e. in an area of significant increase in slope gradient) reaching maximum widths and depths of up to 400 and $80 \mathrm{~m}$, respectively.

The channel orientation changes repeatedly. An abrupt change in orientation from a SE-NW to SSW-NNE occurs at $\sim 1575 \mathrm{~m}$ water depth. Within the following $4 \mathrm{~km}$ in downslope direction, the orientation changes again to SENW. It remains constant over approximately $20 \mathrm{~km}$, until c. $2300 \mathrm{~m}$ water depth where it changes into a SSE-NNW direction. Within the slide scars, the channel orientation changes from SSE-NNW to E-W, before it enters into SFZ.

Slope angles of the channel sidewalls are up to $30^{\circ}$. Cross section is often slightly asymmetric with the northern wall (right side in downslope direction), being slightly steeper than the southern wall. Minor escarpments of maximum $1000 \mathrm{~m}$ width occur on both walls. They are typically more abundant and larger on the northern side.

Several barely visible incisions in the vicinity of the main channel are interpreted to be abandoned and draped channel arms (Figs. 3, 4, 5f). One approximately 1-km- 

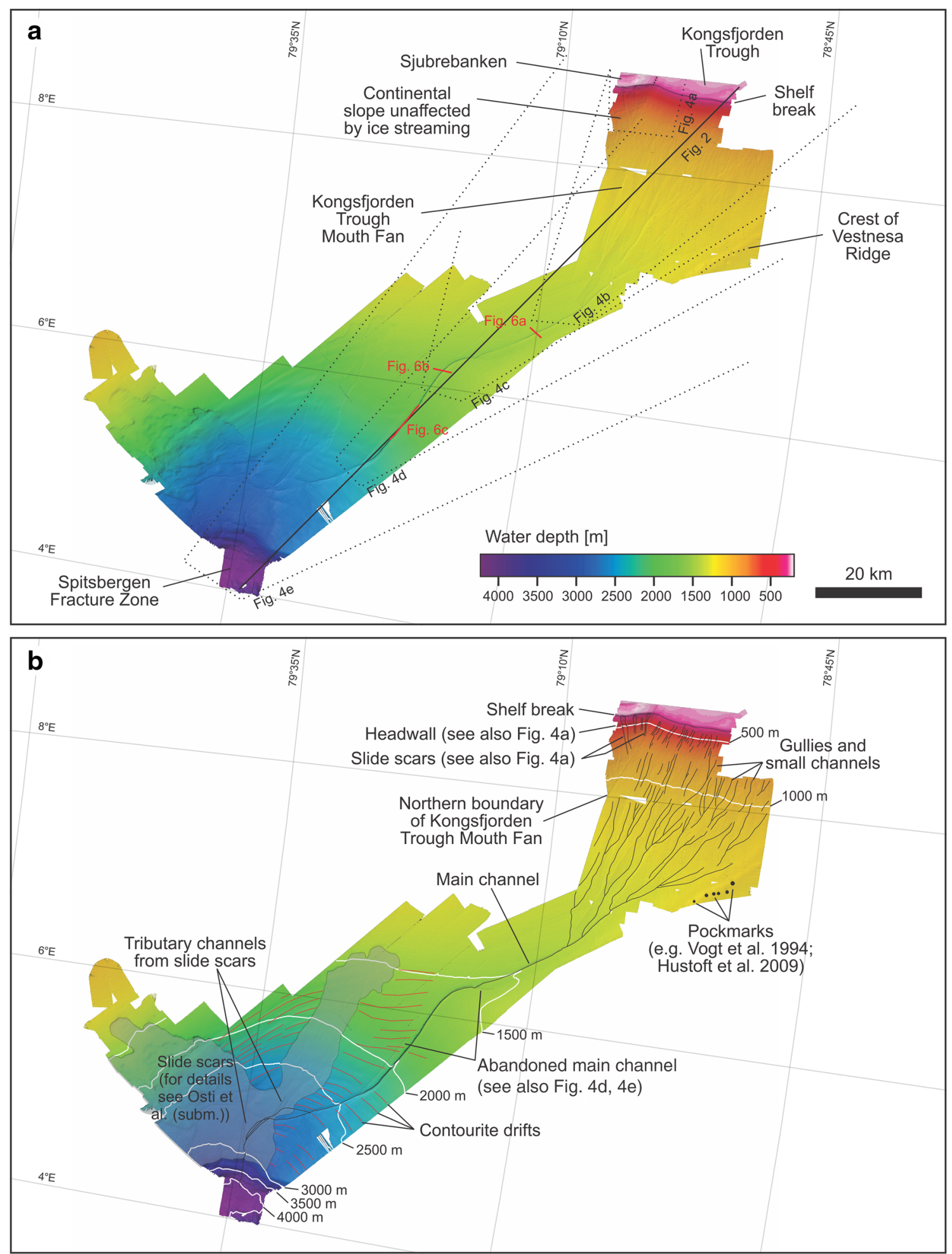

Fig. 3 a Swath bathymetry of the study area. Locations of features/landforms mentioned in the text, as well as references to other figures, are indicated. b Interpretations of landforms

long, 150-m-wide and 7-m-deep incision merges with the main channel from the SSW at $\sim 1560 \mathrm{~m}$ (Fig. 4c). The base of this abandoned channel is approximately $10-15 \mathrm{~m}$ shallower than the thalweg and forms a 'hanging valley' at the point of entry into the main channel. Another less welldeveloped channel appears at $\sim 1800 \mathrm{~m}$ water depth 

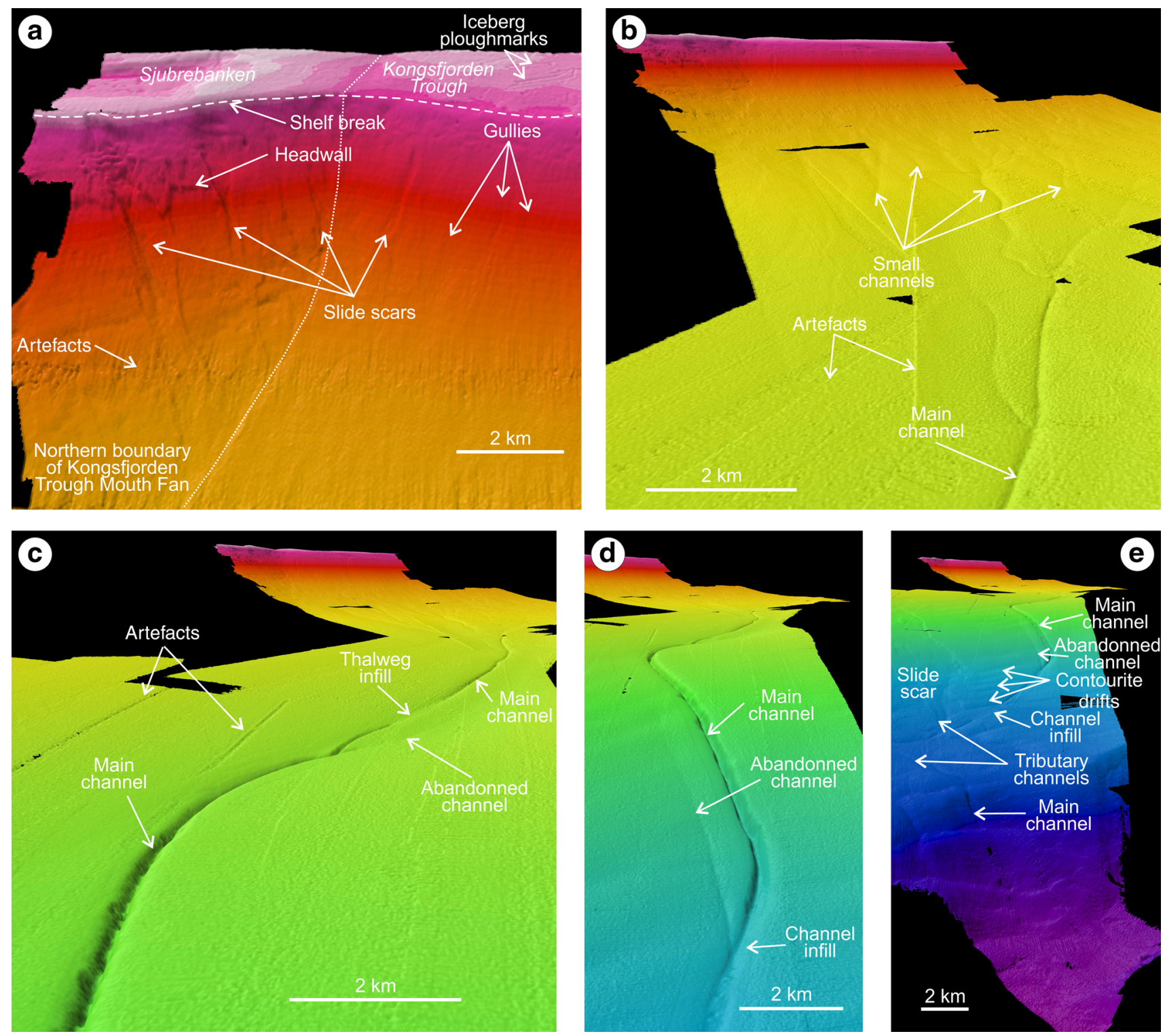

Fig. 4 Zoom-ins of selected parts of the study area. For colour scale, see Fig. 3a. The slide scar in e is described by Osti et al. [50]

approximately $1.5 \mathrm{~km}$ north of the main channel (Fig. 4d). It is less than $10 \mathrm{~m}$ deep and maximum $300 \mathrm{~m}$ wide. It is oriented subparallel to the main channel and merges with the latter at $2400 \mathrm{~m}$. Well-developed levees, as observed in other channel systems on glaciated continental margins (e.g. [29, 34]), are not present in this setting.

\section{Seismostratigraphy}

The uppermost approximately $50 \mathrm{~m}$ of the subseafloor area are predominantly acoustically stratified, typically with stratiform reflections (Fig. 6). Spacing between reflections is generally denser within the uppermost $12 \mathrm{~m}$ (Fig. 6a) to $15 \mathrm{~m}$ (Fig. 6b). The acoustic stratification is suggested to be caused by changes in lithological composition related to variations in bottom-current velocities, transitions between glacials and interglacials and/or very rare overflow from turbidity flows.

Reflections incline towards the channel axis in the uppermost $25 \mathrm{~m}$ beneath the seafloor at $\sim 1450 \mathrm{~m}$ water depth (Fig. 6a) and $40 \mathrm{~m}$ at $\sim 1630 \mathrm{~m}$ water depth (Fig. 6b), respectively. As the inclination increases with decreasing depth below the seafloor, we suggest that the channel has been active from its time of formation and until relatively recently (compare with increasing inclination of reflections indicating the recent activity of pockmarks, e.g. [18, 27, 53]). 
Fig. 5 Cross-profiles along the Kongsfjorden Channel System

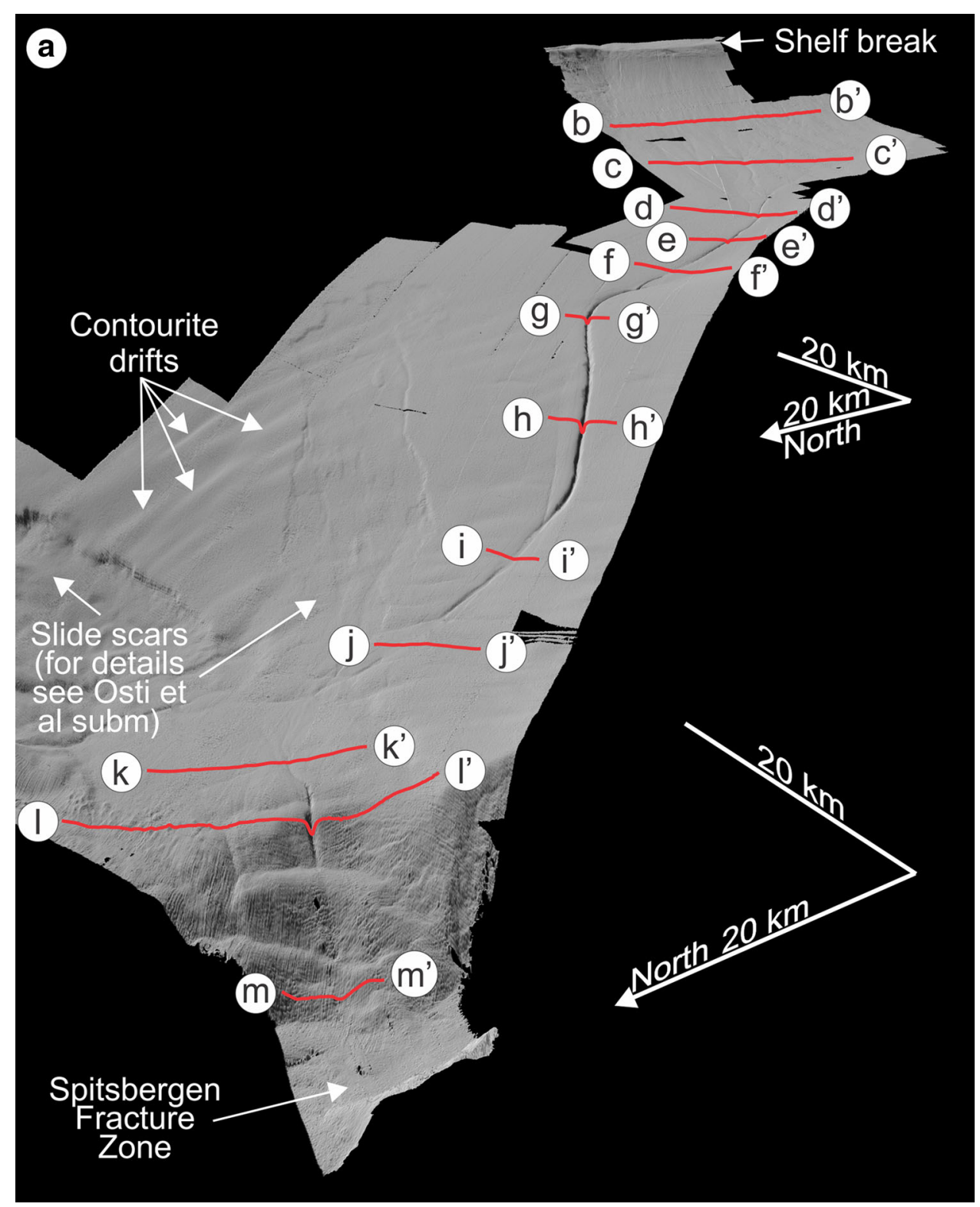

Local variations in the overall reflection pattern appear at various water depths, as well as on either side of the channel. Occasional downlap SW of the channel at $\sim 1450 \mathrm{~m}$ (Fig. 6a) is probably related to the migration of contourite drifts.

Multiple acoustically transparent bodies with more or less uniform thicknesses of up to $4 \mathrm{~m}$ and strong bounding reflections occur 15-25 m below the seafloor (Fig. 6b). These bodies partly truncate underlying acoustically stratified deposits. They are suggested to be overbank deposits originating from overspill or flow-stripping due to the relatively strong curvature of the channel axis from SSWNNE to SE-NW at $\sim 1575 \mathrm{~m}$ water depth (compare with $[47,52,54])$.

\section{Thalweg}

The chirp data reveal multiple up to 20-30-m-high obstacles with up to $3 \mathrm{~km}$ length along the channel axis between $\sim 1850$ and $2400 \mathrm{~m}$ water depths, i.e. in a comparatively steep interval of the continental slope (Fig. 6c). Several of these obstacles have a steeper stoss side (upslope) than lee side (downslope). Strong uppersurface reflections are probably caused by a relatively coarse granulometric composition of the thalweg surface due to erosion of fine-grained deposits and/or deposition of coarser grains.

Acoustic stratification occurs within some of the obstacles. Whether or not these internal reflections are 

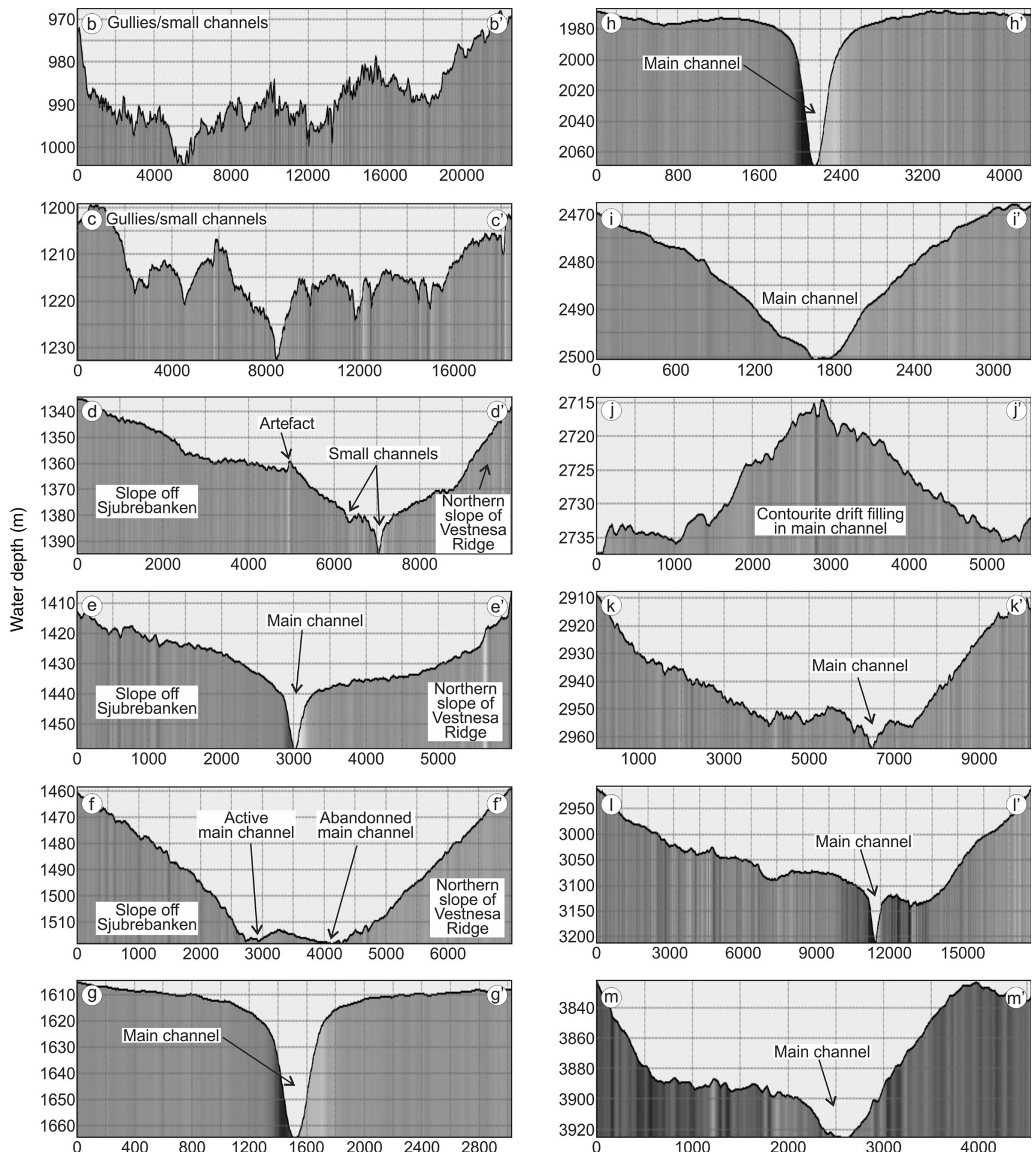

Fig. 5 continued

real or artefacts caused from side reflections cannot be inferred from the available data. However, acoustic stratification beneath the obstacles is assumed to originate from unaffected slope deposits underlying the channel axis.
The occurrence of these obstacles may have multiple explanations. They can be (1) artefacts; (2) mass-transport deposits originating from failure at the channel side; (3) 'original deposits' of limited extent that have not been eroded from bypassing gravity flows. 

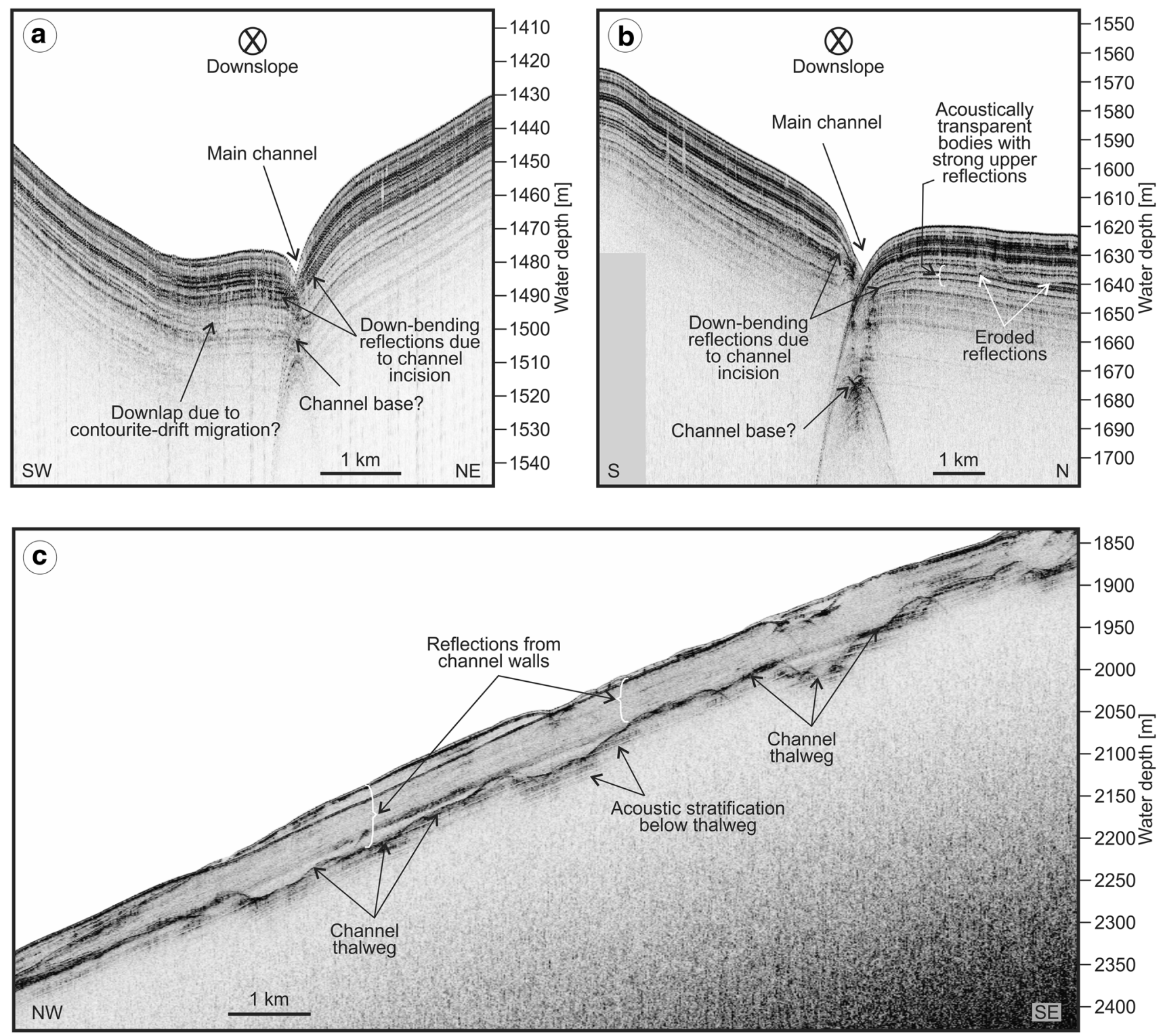

Fig. 6 Penetration echo sounder profiles and interpretations. For locations, see Fig. 3a

\section{Discussion}

\section{Geographical constraints on channel location and shape}

The regional bathymetry and changes in slope gradients determine the location and shape of the KCS. The relatively straight shape of the gullies in the shallowest part of the study area is probably the result of the steep slope of the Kongsfjorden TMF (Figs. 2, 3, 4a).

The small channels between $\sim 1150$ and $1400 \mathrm{~m}$ water depths occur in an area with the lowest slope gradients in the entire study area (Figs. 2, 3, 4b) allowing some lateral migration and the development of a partly sinuous shape.
However, the slopes of Sjubrebanken and the northern slope of the Vestnesa Ridge 'force' these small channels to merge gradually into the main channel at around $1400 \mathrm{~m}$ water depth (Figs. 3, 4b, 5).

The shallowest part of the main channel (below $\sim 1600 \mathrm{~m})$ is relatively straight, even though it occurs within an area of low slope gradient as the sinuous smaller channels at shallower water depth (Figs. 2, 3, 4). This difference is explained by lateral constraints exposed by the slopes off Sjubrebanken and the northern slope of the Vestnesa Ridge, respectively (Fig. 5e, f), preventing lateral migration of the channel.

The main channel has its largest width and depth, as well as the steepest sidewalls, between $\sim 1530$ and $2400 \mathrm{~m}$ 
water depth (Figs. 3, 4, 5g, h), i.e. in an area of relatively steep slope gradients (Fig. 2). As laterally constraining slopes are absent (compared to shallower depths), the increase in slope gradient appears to be the main factor forcing the channel to change its direction at $\sim 1575 \mathrm{~m}$ water depth and leading to its straight morphology.

Below $2400 \mathrm{~m}$ water depth, slope gradients decrease again and the location of the channel appears to be confined by the ambient slopes (Figs. 2, 3, 4, 5i). However, below $2900 \mathrm{~m}$, the marked increase in slope gradient controls the location of the channel and leads to the reestablishment of a wide and deep morphology, similar to between $\sim 1530$ and $2400 \mathrm{~m}$.

\section{Age and formation mechanisms}

Inclined reflections on chirp profiles acquired from $\sim 1600 \mathrm{~m}$ water depth indicate that the channel system has been active during the deposition of approximately $40 \mathrm{~m}$ of sediment (Fig. 6b). The establishment of an absolute chronology for the initiation of channel activity remains, however, challenging, because well-dated long sediment records from the study area are not available.

Mattingsdal et al. [41] present seismic data from southern Sjubrebanken. They dated a reflection at 80-100 ms two-way travel time (TWT; $<100 \mathrm{~m}$; their 'blue reflection') below the seafloor to $\sim 1.5 \mathrm{Ma}$. It should be noted that lateral variations in sedimentation rates on glaciated continental margins occur and that sedimentation rates on banks are typically reduced due to winnowing (e.g. [69]. Based on this, we regard 1.5 Ma as a maximum age for channel initiation.

Sarkar et al. [61] present seismic profiles from the vicinity of the chirp profiles presented here. They assign their reflection $\mathrm{A} 3$ an age of $0.78 \mathrm{Ma}$. This reflection appears less than a few tens of milliseconds TWT $(<40 \mathrm{~m})$ below the seafloor. Based on this, we infer that the formation of the channel commenced prior to $0.78 \mathrm{Ma}$. In conclusion, we suggest that channel formation commenced between 1.5 and $0.78 \mathrm{Ma}$, closer to the latter.

Contourite-drift deposition in the eastern Fram Strait has taken place at least since $11 \mathrm{Ma}[7,41,61]$. The formation of the KCS requires, therefore, a distinct and relatively recent change to enhanced activity of downslope processes.

The first extent of grounded ice streams to the continental margin off northwest Spitsbergen led to the development of the Sjubrebanken Fan from $\sim 2.7$ Ma [41, 61]. A major switch in the location of the ice stream to the Kongsfjorden Trough and the formation of the Kongsfjorden TMF occurred around 1.5 Ma [41] or between 1.5 and $0.99 \mathrm{Ma}$ [61].

Since the KCS commences on the Kongsfjorden TMF and since it formed between 1.5 and $0.78 \mathrm{Ma}$, we suggest that its initiation and activity are mainly related to the advance of grounded ice through the Kongsfjorden Trough to the shelf break. This occurred probably from shortly after $1 \mathrm{Ma}$, when glacial activity in the Barents Sea region intensified (see [28]).

\section{Sediment sources and sedimentary processes}

TMFs are protrusions of the shelves on glaciated continental margins. They formed from repeated slope failure related to the supply of vast amounts of sediment to the shelf break during peak glaciations (e.g. [30, 31, 70, 71]). They can be subdivided into low-gradient and high-gradient TMFs, respectively [60]. Based on Rydningen et al. [60], low-gradient TMFs have surface inclinations of $0.5^{\circ}$ $1.0^{\circ}$, whereas the surfaces of high-gradient TMFs typically have slope angles of $1^{\circ}-15^{\circ}$. Thus, the Kongsfjorden TMF, having slope angles up to $12^{\circ}$, can be defined as a highgradient TMF. It formed during multiple glaciations, including the last glacial, when fast-flowing, grounded ice reached the shelf break off northwest Spitsbergen repeatedly [38-41, 51, 61, 70, 71].

The KCS originates at the shelf break of the Kongsfjorden Trough, where multiple gullies provide evidence of small-scale erosion into the continental slope, as observed in other Arctic channel systems (e.g. [8, 19, 71]). Gully formation has probably mainly taken place during glaciations when grounded ice reached the mouth of the Kongsfjorden Trough. Various mechanisms may have led to their formation, including descending dense water masses rejected from brine formation, turbidity flows beyond the mouths of glacial troughs or retrogressive slope failure (compare with [8, 19, 43, 48, 60, 71]). Sediment supply into the gully system may also have occurred during interglacials, due to winnowing of fine-grained material from the upper parts of the continental slope (compare, e.g. with [2, 60]). However, sediment flux has most probably been significantly lower compared to glacials.

Sakar et al. [61] suggest that the Kongsfjorden TMF is composed of debris flows. However, our bathymetry data do not reveal any evidence of debris-flow lobes as extensive and voluminous as observed on low-angle TMFs (compare, e.g. with [30, 31, 71]). This may indicate that (1) debris flows forming beyond the Kongsfjorden Trough were generally small and/or (2) debris flows originating at the shelf break, or slightly below, detached from the seafloor on the steep upper slope of the Kongsfjorden TMF and travelled through the KCS by hydroplaning (compare with, e.g. [32]) and/or (3) debris flows transformed and disintegrated into turbidity flows (compare with, e.g. [9, 60]). 
The absence of depositional features/intervals within the channel(s) suggests that sediments are evacuated from/ 'flushed out' of the active system. Furthermore, the absence of well-developed levee systems indicates that turbidity flows were generally small and confined to the channels.

Multiple minor escarpments along the steep sidewalls of the main channel provide evidence of repeated slope failure and 'internal' sediment supply to the system. The failures can have resulted from oversteepening and failure of these up to $30^{\circ}$ steep walls or from undercutting of the northern slopes (note the partly asymmetric cross-profile of the main channel, e.g. Fig. 5h; compare with [44]). As the study area is located close to the SFZ, we also regard the release of tectonic stress (compare with [55]) as a potential trigger for failures on the sidewalls. The failed material was either immediately evacuated or subsequently eroded by subsequent gravity flows.

The comparatively deep and wide incision of the channel between $\sim 1530$ and $2300 \mathrm{~m}$ and below $2960 \mathrm{~m}$ suggests that the erosive behaviour of focused downslope processes exceeds along-slope processes in steeper areas of the continental slope (Figs. 2, 4, 5). However, in less inclined areas, e.g. around $1500 \mathrm{~m}$ and between 2680 and $2960 \mathrm{~m}$, the channel is partly to entirely filled (Figs. 4d, $5 \mathrm{j}$ ). We suggest that these infills are composed of contourite drifts, rather than being deposited from decelerating turbidity/debris flows. We assume that the turbidity/debris flows (1) have a state of hydroplaning allowing them to cross these areas without (or only with minor) erosion (compare with [11, 32, 45]) and/or (2) travel around the contourite drifts before being 'forced back' into the main channel by the overall topography in the area.

\section{Comparison of high-latitude channel systems}

Channel systems on and off glaciated continental margins are prominent features of various sizes and configurations occurring at a wide range of water depths. Their activity was maintained by a variety of downslope processes transferring sediment from the shelf break/upper continental slope to the deep sea. As the activity often correlates with glacial activity, some channel systems can provide valuable archives to study the dynamics of past ice sheets. A summary of various properties/characteristics of selected channel systems in the Arctic and Antarctica is presented in Table 1 and discussed below.

Whereas other channel systems extend over several hundreds of kilometres and onto extensive abyssal plains continuing off the respective continental slopes, the maximum possible extent of the KCS is constrained by the shelf break and the SFZ. As a consequence, the KCS is, with its $120 \mathrm{~km}$ length, one of the shortest systems
(Table 1). However, even though it is comparatively short, it covers the largest depth range $(250-4000 \mathrm{~m}$ water depth). Furthermore, it crosses submarine slopes with the largest variety of inclinations compared to the other systems $\left(0^{\circ}-20^{\circ}\right)$. Being maximum $500 \mathrm{~m}$ wide, the $\mathrm{KCS}$ is typically at least one order of magnitude narrower than other channels that can reach widths of up to $20 \mathrm{~km}$. However, despite this, it belongs to the deeper channel systems (Table 1). The deepest incisions occur in areas with the steepest slope gradients allowing the gravity flows to accelerate and erode deeper into the subseafloor than in less-steep inclined areas.

The overall location of the largest channel systems is controlled by the general increase in water depth without any influence of lateral obstacles allowing lateral migration occasionally over tens of kilometres (NP-28; Table 1). However, the orientation of smaller systems is often controlled by other factors including bordering by TMFs (e.g. INBIS Channel), canyon walls (Central Scotian Slope), sediment drifts (North Antarctic Peninsula) or the ambient large-scale bathymetry which, in case of the KCS, is defined by the slopes off Sjubrebanken and the Vestnesa Ridge. Thus, these smaller systems remain often laterally relatively stable.

Channel systems on glaciated continental margins originate mostly in the continuations of glacial troughs that formed when fast-flowing grounded ice streams transport vast amounts of sediment to the shelf break during repeated glaciations (Table 1). These ice streams acted often as sources for processes leading to incision and channel formation (see below). However, occasionally, channel formation is pre-defined by the existence of large canyons (e.g. Lofoten Basin Channel, Central Scotian Slope).

The oldest channel systems formed around $2.5 \mathrm{Ma}$ (off East Greenland, NP-28; Table 1), i.e. the systems formed after the onset of enhanced northern hemisphere glaciations. The systems were typically most active during peak glaciation when ice streams reached their maximum extents, delivering extensive amounts of sediment to the shelf break and the heads of the channel systems. Failure of these sediments led to the formation of debris and/or turbidity flows. However, turbidity flows could also originate directly from hyperpycnal flows of cold and sediment-laden glacial meltwater at the ice margin or from brine rejection during the formation of sea ice during periods, when grounded ice did not extend to the shelf break. Furthermore, sediment supply could also occur from failure along canyon/channel walls (Central Scotian Slope, North Antarctic Peninsula, KCS), as well as from winnowing (Lofoten Basin Channel, KCS) during glacials and interglacials.

The dominant agent maintaining high-latitude channel systems is turbidity flows (Table 1). These flows can move 


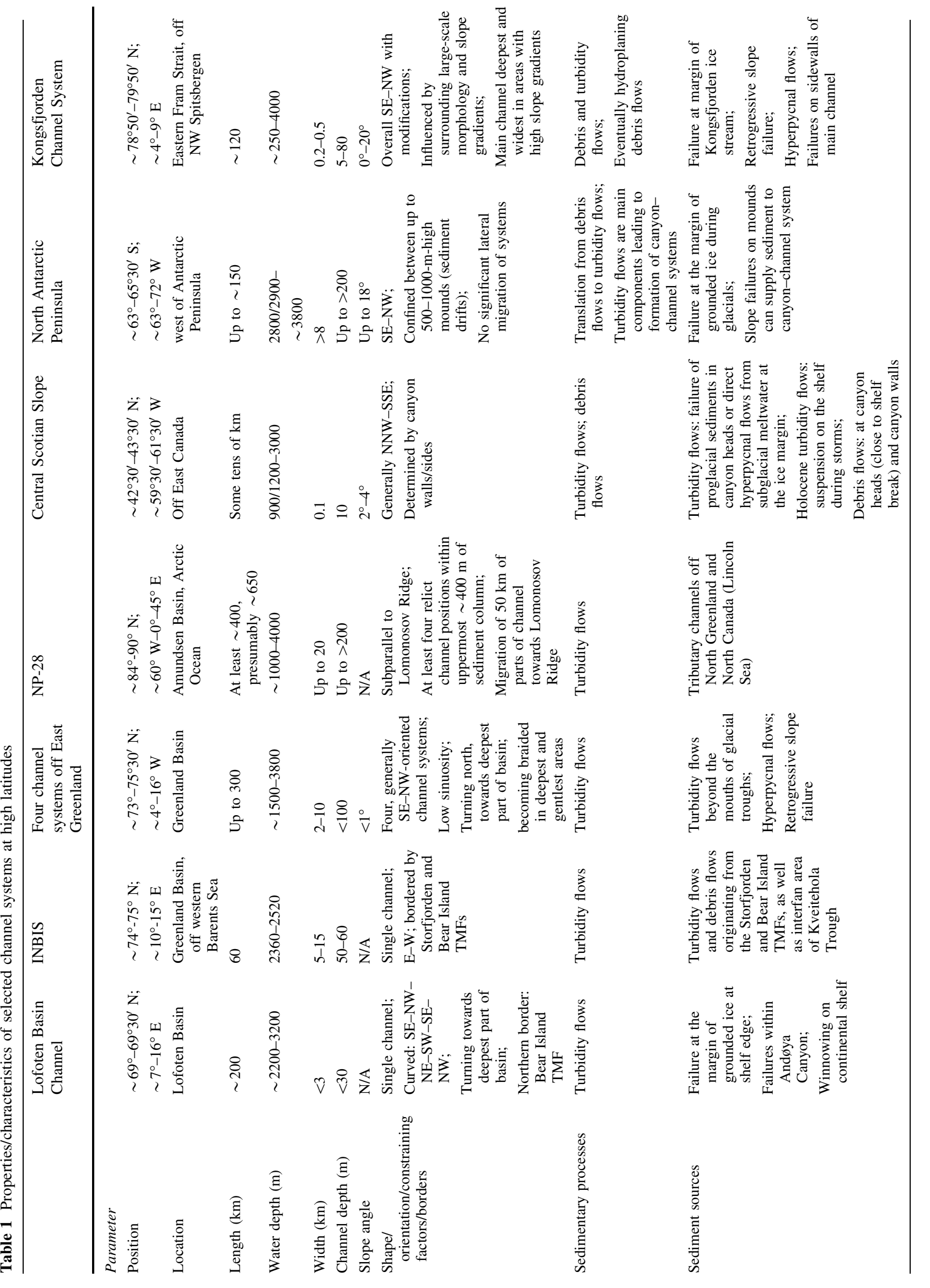




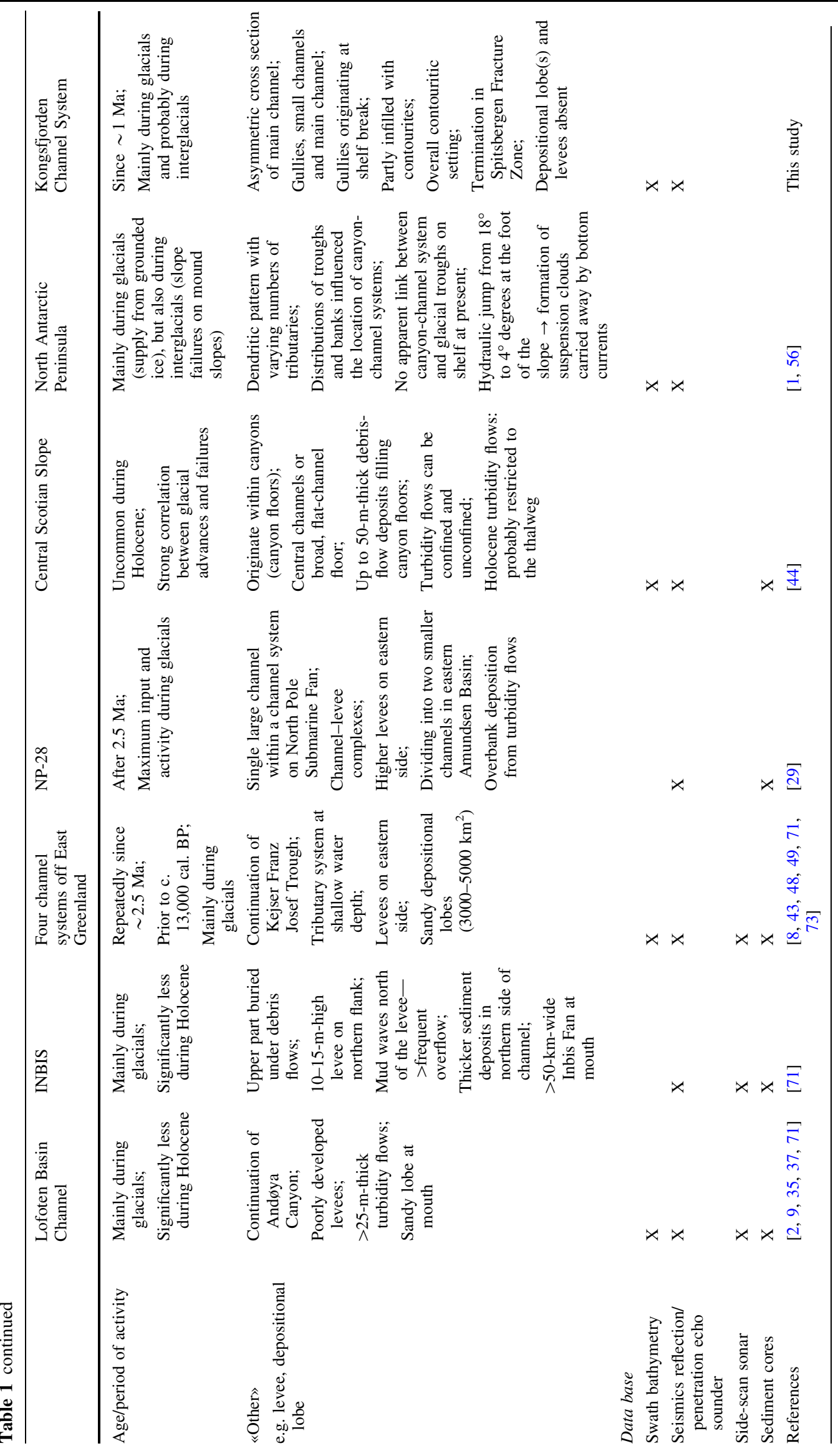


as confined flows over several hundreds of kilometres often leading to the deposition of extensive sandy lobes beyond the channel mouths. However, lobe deposition at the mouth of the KCS is absent, because the SFZ prevents flows from spreading out laterally. This leads to aggradation, rather than progradation beyond the termination of the system. Turbidity flows can occasionally also spread out beyond the lateral limits of the channels. This occurs, e.g. in the form of overflows leading to the formation of poorly to well-developed levees and overbank deposits (see examples from the Atlantic and Arctic Oceans), but it can also be related to hydraulic jumps due to marked changes in slope gradients at the foot of the slope (North Antarctic Peninsula).

It has also been suggested that debris flows can play a certain role in channel development. The deposits of debris flows can either fill the canyon floor (Central Scotian Slope), the flows can disintegrate into turbidity flows (e.g. North Antarctic Peninsula), or they might pass through the system by hydroplaning (KCS).

\section{Conclusions}

Swath bathymetry and penetration echo sounder data have been analysed to investigate the morphology, processes and time of activity of the KCS on the continental slope off northwest Svalbard. The main conclusions are:

- The KCS is located in a contouritic setting between the mouth of the Kongsfjorden Trough and the Spitsbergen Fracture Zone where slope gradients vary between $\sim 0^{\circ}$ and $20^{\circ}$. It is approximately $120 \mathrm{~km}$ long and ranges from $\sim 250$ to $4000 \mathrm{~m}$ water depth. It includes multiple gullies on the Kongsfjorden TMF, as well as few incisions resulting from slope failures, merging to small channels that further merge to a main channel. Maximum channel width and depth are 500 and $80 \mathrm{~m}$, respectively.

- The location and orientation of the channel system are controlled by the ambient regional bathymetry and variations in slope gradients.

- The system has probably been active since $\sim 1 \mathrm{Ma}$, when glacial activity increased and grounded ice repeatedly expanded to the shelf break to form the Kongsfjorden TMF. The system was presumably most active during glacials when grounded ice delivered high amounts of sediment to the shelf break by grounded ice, leading to slope failures and the formation of debris flows and/or turbidity flows. However, some-though significantly reduced-activities may have occurred during interglacials.
- The absence of well-developed channel-levee complexes indicates that turbidity currents were relatively small and confined, and that overspill is absent or occurred rarely.

- The absence of large debris-flow lobes may indicate that debris flows originating off the Kongsfjorden Trough during the last glacial were generally small. Furthermore, debris flows either presumably disintegrated into turbidity flows or travelled through the system by hydroplaning.

- Whereas the main channel is deeply incised and void of any deposits along the thalweg in the steeper parts of the continental slope, contourite drifts partly fill the channel in areas with gentler gradients. The absence of erosion in these parts may reflect that the downslope moving flows cross the areas of infill by hydroplaning or that they move around the elevations before being forced back into the main channel.

- The main differences of the KCS compared to other channel systems on glaciated continental margins are that it is relatively short, covers a large range of water depth on a relatively steep slope and is that the main channel relatively deep compared to its width.

- The results of this and other studies show that submarine channel systems at high latitudes can provide valuable tools for the reconstruction of past ice-sheet dynamics.

Acknowledgements Data collections took place as part of the project Depositional Models for Cenozoic Sandy Systems (DEMOCEN) funded by the Research Council of Norway. During the time of data collection, MF was partly funded by Det norske oljeselskap ASA. GO is affiliated to CAGE-Center for Arctic Gas Hydrate, Environment and Climate (Grant 223259 of the Research Council of Norway). The captains and crews of R/V Jan Mayen (now R/V Helmer Hanssen), as well as Steinar Iversen, Jan P. Holm and Torger Grytå, supported this work during and after data collection. Two anonymous referees provided constructive comments improving the manuscript. We extend our most sincere thanks to these persons and institutions.

\section{References}

1. Amblas D, Urgeles R, Canals M, Calafat AM, Rebesco M, Camerlenghi A, Estrada F, De Batist M, Hughes-Clarke JE (2006) Relationship between continental rise development and palaeo-ice sheet dynamics, Northern Antarctic Peninsula Pacific Margin. Quat Sci Rev 25:933-944

2. Amundsen HB, Laberg JS, Vorren TO, Haflidason H, Forwick M, Buhl-Mortensen P (2015) Late Weichselian-Holocene evolution of the high-latitude Andøya submarine Canyon, North-Norwegian continental margin. Mar Geol 363:1-14

3. Baeten NJ, Laberg JS, Forwick M, Vorren TO, Vanneste M, Forsberg CF, Kvalstad TJ, Ivanov M (2013) Morphology and origin of smaller-scale mass movements on the continental slope off northern Norway. Geomorphology 187:122-134 
4. Beszczynska-Möller A, Fahrbach E, Schauer U, Hansen E (2012) Variability in Atlantic water temperature and transport at the entrance to the Arctic Ocean, 1997-2010. ICES J Mar Sci 69:852-863

5. Bloom AL (1991) Geomorphology—a systematic analysis of late cenozoic landforms. Prentice Hall, Englewood Cliffs, NJ

6. Bugge T (1983) Submarine slides on the Norwegian continental margin, with special emphasis on the Storegga area, vol 110. Continental Shelf and Petroleum Research Institute Publication, Trondheim, Norway

7. Eiken O, Hinz K (1993) Contourites in the Fram Strait. Sed Geol 82:15-32

8. Dowdeswell JA, Ó Cofaigh C, Taylor J, Kenyon NH, Mienert J, Wilken M (2002) On the architecture of high-latitude continental margins: the influence of ice-sheet and sea-ice processes in the Polar North Atlantic. In: Dowdeswell JA, Ó Cofaigh C (eds) Glacier-influenced sedimentation on high-latitude continental margins. Geol Soc Spec Publ 230:33-54

9. Dowdeswell JA, Kenyon NH, Elverhøi A, Laberg JS, Hollender FJ, Mienert J, Siegert MJ (1996) Large-scale sedimentation on the glacier-influence Polar North Atlantic margins: long-range side-scan sonar evidence. Geophys Res Lett 23:3535-3538

10. Elger J, Berndt C, Krastel S, Piper DJW, Gross F, Spielhagen RF, Meyer S (2014) The Fram Slide off Svalbard: a submarine landslide on a low-sedimentation-rate glacial continental margin. J Geol Soc 172:153-156

11. Elverhøi A, Harbitz CB, Dimakis P, Mohrig D, Marr J, Parker G (2000) On the dynamics of subaqueous debris flows. Oceanography 13:109-117

12. Engen $\varnothing$, Faleide JI, Dyreng TK (2008) Opening of the Fram Strait gateway: a review of plate tectonic constraints. Tectonophysics 450:51-69

13. Fahrbach E, Meincke J, Østerhus S, Rohardt G, Schauer U, Tverberg V, Verduin J (2001) Direct measurements of volume transports through Fram Strait. Polar Res 20:217-224

14. Faugères JC, Stow DAV (2008) Contourite drifts: nature, evolution and controls. In: Rebesco M, Camerlenghi A (eds) Contourites. Dev Sedimentol 60:259-288

15. Forwick M (2009) Cruise report-marine-geological cruise to West Spitsbergen fjords and the Fram Strait—on R/V Jan Mayen, October 26th-November 1st 2008

16. Forwick M (2009) Cruise report-marine-geological cruise to Spitsbergen fjords, the Fram Strait and the northern Barents Sea-on R/V Jan Mayen, October 27th-November 7th 2009

17. Forwick M (2010) Cruise report-marine-geological cruise to Spitsbergen fjords, the Fram Strait and Storfjorden-on R/V Jan Mayen, October 25th-November 4th 2010

18. Forwick M, Baeten NJ, Vorren TO (2009) Pockmarks in Spitsbergen fjords. Nor J Geol 89:65-77

19. Gales JA, Forwick M, Laberg JS, Vorren TO, Larter RD, Graham AGC, Baeten NJ, Amundsen HB (2013) High-latitude continental slope geomorphology: a comparison of some Arctic and Antarctic submarine gullies. Geomorphology 201:449-461

20. Gascard JC, Richez C, Rouault C (1995) New insights on largescale oceanography in Fram Strait: The West Spitsbergen Current. In: Smith W, Grebmeier J (eds) Arctic oceanography: marginal ice zones and continental shelves, coastal estuarine studies. AGU, Washington D.C., pp 131-182

21. Gebhardt AC, Jokat W, Niessen F, Matthiessen J, Geissler WH, Schenke HW (2011) Ice sheet grounding and iceberg plow marks on the northern and central Yermak Plateau revealed by geophysical data. Quat Sci Rev 30:1726-1738

22. Hass HC (2002) A method to reduce the influence of ice-rafted debris on a grain size record from northern Fram Strait, Arctic Ocean. Polar Res 21:299-306
23. Howe JA, Shimmield TM, Harland R (2008) Late Quaternary contourites and glaciomarine sedimentation in the Fram Strait. Sedimentology 55:170-200

24. Hustoft S, Bünz S, Mienert J, Chand S (2009) Gas hydrate reservoir and active methane-venting province in sediments on $<20 \mathrm{Ma}$ young oceanic crust in the Fram Strait, offshore NWSvalbard. Earth Planet Sci Lett 284:12-24

25. Jakobsson M, Backman J, Rudels B, Nycander J, Frank M, Mayer L, Jokat W, Sangiorgi F, O'Regan M, Brinhuis H, King J, Moran K (2007) The early Miocene onset of a ventilated circulation regime in the Arctic Ocean. Nature 447:986-990

26. Jessen SP, Rasmussen TL, Nielsen T, Solheim A (2010) A new Late Weichselian and Holocene marine chronology for the western Svalbard slope 30,000-0 cal years BP. Quat Sci Rev 29:1301-1312

27. Josenhans HW, King LH, Fader GB (1978) A side-scan sonar mosaic of pockmarks on the Scotian Shelf. Can J Earth Sci $15: 831-840$

28. Knies J, Matthiessen J, Vogt C, Laberg JS, Hjelstuen BO, Smelror M, Larsen E, Andreassen K, Eidvin T, Vorren TO (2009) The Plio-Pleistocene glaciation of the Barents Sea-Svalbard region: a new model based on revised chronostratigraphy. Quat Sci Rev 28:812-829

29. Kristoffersen Y, Sorokin MY, Jokat W, Svendsen O (2004) A submarine fan in the Amundsen Basin, Arctic Ocean. Mar Geol 204:317-324

30. Laberg JS, Vorren TO (1995) Late Weichselian submarine debris flow deposits on the Bear Island Trough Mouth Fan. Mar Geol 127:45-72

31. Laberg JS, Vorren TO (1996) The Middle and Late Pleistocene evolution of the Bear Island Trough Mouth Fan. Glob Planet Change 12:309-330

32. Laberg JS, Vorren TO (2000) Flow behaviour of the submarine glacigenic debris flows on the Bear Island Trough Mouth Fan, western Barents Sea. Sedimentology 47:1105-1117

33. Laberg JS, Dahlgren T, Vorren TO, Haflidason H, Bryn P (2001) Seismic analyses of Cenozoic contourite drift development in the Northern Norwegian Sea. Mar Geophys Res 22:401-416

34. Laberg JS, Guidard S, Mienert J, Vorren TO, Haflidason H, Nygård A (2007) Morphology and morphogenesis of a high-latitude canyon: the Andøya Canyon, Norwegian Sea. Mar Geol 246:68-85

35. Laberg JS, Johannessen HB, Forwick M, Ivanov M, Vorren TO (2011) Extensive erosion of the deep sea floor-implications for the behavior and frequency of flows resulting from continentalslope instability. In: Yamada Y, Kawamura K, Ikehara K, Ogawa Y, Urgeles R, Mosher D, Chaytor J, Strasser M (eds) Submarine mass movements and their consequences. Adv Nat Technol Hazards Res 31:159-166

36. Laberg JS, Stoker MS, Dahlgren KIT, de Haas H, Haflidason H, Hjelstuen BO, Nielsen T, Shannon PM, Vorren TO, van Weering TCE, Ceramicola S (2005) Cenozoic alongslope processes and sedimentation on the NW European Atlantic margin. Mar Pet Geol 22:1069-1088

37. Laberg JS, Vorren TO, Kenyon NH, Ivanov M, Andersen ES (2005) A modern canyon-fed sandy turbidite system of the Norwegian continental margin. Nor J Geol 85:267-277

38. Landvik JY, Bondevik S, Elverhøi A, Fjeldskaar W, Mangerud J, Salvigsen O, Siegert MJ, Svendsen JI, Vorren TO (1998) The last glacial maximum of Svalbard and the Barents Sea area: ice sheet extent and configuration. Quat Sci Rev 17:43-75

39. Landvik JY, Ingólfsson Ó, Mienert J, Lehman SJ, Solheim A, Elverhøi A, Ottesen D (2005) Rethinking Late Weichselian ice sheet dynamics in coastal NW Svalbard. Boreas 34:7-24 
40. Mangerud J, Dokken T, Hebbeln D, Heggen B, Ingólfsson Ó, Landvik JY, Mejdahl V, Svendsen JI, Vorren TO (1998) Fluctuations of the Svalbard-Barents Sea ice sheet during the last 150 000 years. Quat Sci Rev 17:11-42

41. Mattingsdal R, Knies J, Andreassen K, Fabian K, Husum K, Grøsfjeld K, De Schepper S (2014) A new 6 Myr stratigraphic framework for the Atlantic-Arctic Gateway. Quat Sci Rev 92:170-178

42. Micallef A, Muntjoy JJ, Barnes PM, Canals M, Lastras G (2014) Geomorphic response of submarine canyons to tectonic activity: insights from the Cook Strait canyon system, New Zealand. Geosphere 10:905-929

43. Mienert J, Kenyon NH, Thiede J, Hollender FJ (1993) Polar continental margins: studies off East Greenland. EOS 74:225, 231, 234, 236

44. Mosher DC, Piper DJW, Campbell DC, Jenner KA (2004) Nearsurface geology and sediment-failure geohazards of the central Scotian Slope. AAPG Bull 88:703-723

45. Mulder T, Alexander J (2001) The physical character of subaqueous sedimentary density flows and their deposits. Sedimentology 48:269-299

46. Normark WR, Carlson PR (2003) Giant submarine canyons: is size any clue to their importance in the rock record? In: Chan MA, Archer AW (eds) Extreme depositional environments: mega end members in geologic time. Geol Soc Am Spec Pap 370:175-190

47. Normark WR, Piper DJW (1984) Navy Fan, California Borderland: growth pattern and depositional processes. Geo Mar Lett 3:101-108

48. Ó Cofaigh C, Dowdeswell JA, Evans J, Kenyon NH, Taylor J, Mienert J, Wilken M (2004) Timing and significance of glacially influenced mass-wasting in the submarine channels of the Greenland Basin. Mar Geol 207:39-54

49. Ó Cofaigh C, Taylor J, Dowdeswell JA, Rosell-Melé A, Kenyon NH, Evans J, Mienert J (2002) Sediment reworking on highlatitude continental margins and its implications for palaeoceanographic studies: insights from the Norwegian-Greenland Sea. In: Dowdeswell JA, Ó Cofaigh C (eds) Glacier-influenced sedimentation on high-latitude continental margins. Geol Soc Spec Pub 230:325-348

50. Osti G, Mienert J, Laberg JS, Forwick M (subm) Multiple slope failures shaped the lower continental slope offshore NW Svalbard in the Fram Strait. Submitted to Mar Geol

51. Ottesen D, Dowdeswell JA, Rise L (2005) Submarine landforms and the reconstruction of fast-flowing ice streams within a large Quaternary ice sheet: the 2500-km-long Norwegian-Svalbard margin $\left(57^{\circ}-80^{\circ} \mathrm{N}\right)$. Geol Soc Am Bull 117:1033-1050

52. Peakall J, McCaffrey B, Kneller B (2000) A process model for the evolution, morphology, and architecture of sinuous submarine channels. J Sediment Res 70:434-448

53. Pickrill RA (1993) Shallow seismic stratigraphy and pockmarks of a hydrothermally influenced lake, Lake Rotoiti, New Zealand. Sedimentology 40:813-828

54. Piper DJW, Normark WR (1983) Turbidite depositional patterns and flow characteristics, Navy submarine fan, California Borderland. Sedimentology 30:681-694

55. Plaza-Faverola A, Bünz S, Johnson JE, Chand S, Knies J, Mienert J, Franek P (2015) Role of tectonic stress in seepage evolution along the gas hydrate-charged Vestnesa Ridge, Fram Strait. Geophys Res Lett 42:733-742

56. Rebesco M, Pudsey C, Canals M, Camerlenghi A, Barker P, Estrada F, Giorgetti A (2002) Sediment drift and deep-sea channel systems, Antarctic Peninsula Pacific Margin. In: Stow
DAV, Faugères JC, Howe J, Pudsey CJ, Viana A (eds) Deepwater contourite systems: modern drift and ancient series, seismic and sedimentary characteristics. Geol Soc Lond Mem 22:353-371

57. Rebesco M, Wåhlin A, Laberg JS, Schauer U, BeszczynskaMöller A, Lucchi RG, Noormets R, Accettella D, Zarayskaya Y, Diviacco P (2013) Quaternary contourite drifts of the western Spitsbergen margin. Deep-Sea Res I 79:156-168

58. Reece RS, Gulick SPS, Horton BK, Christeson GL, Worthington LL (2011) Tectonic and climatic influence on the evolution of the Surveyor Fan and Channel system, Gulf of Alaska. Geosphere $7: 830-844$

59. Rise L, Bøe R, Riis F, Bellec VK, Laberg JS, Eidvin T, Elvenes S, Thorsnes T (2013) The Lofoten-Vesterålen continental margin, North Norway: canyons and mass-movement activity. Mar Pet Geol 45:134-149

60. Rydningen TA, Laberg JS, Kolstad V (2015) Seabed morphology and sedimentary processes on high-gradient trough mouth fans offshore Troms, northern Norway. Geomorphology 246:205-219

61. Sarkar S, Berndt C, Chabert A, Masson DG, Minshull TA, Westbrook GK (2011) Switching of a paleo-ice stream in northwest Svalbard. Quat Sci Rev 30:1710-1725

62. Schauer U, Fahrbach E, Østerhus S, Rohardt G (2004) Arctic warming through the Fram Strait: oceanic heat transport from 3 years of measurements. J Geophys Res. doi:10.1029/ 2003JC001823

63. Shepard FP (1981) Submarine canyons: multiple causes and longtime persistence. AAPG Bull 65:1062-1077

64. Skene KI, Piper DJW, Hill PS (2002) Quantitative analysis of variations in depositional sequence thickness from submarine channel levees. Sedimentology 49:1141-1430

65. Solli K, Kuvaas B, Kristoffersen Y, Leitchenkov G, Guseva J, Gandjukhin V (2007) A seismo-stratigraphic analysis of glaciomarine deposits in the eastern Riiser-Larsen Sea (Antarctica). Mar Geophys Res 28:43-57

66. STRATAGEM Partners (2002) Stoker, M.S. (Compiler). The Neogene stratigraphy of the glaciated European margin from Lofoten to Porcupine. A Product of the EC-supported STRATAGEM Project. http://stratagem.pangaea.de/

67. Torsvik TH, Carlos D, Mosar J, Cocks LRM, Malme TN (2002) Global reconstructions and North Atlantic paleogeography $440 \mathrm{Ma}$ to recent. In: Eide EA (ed) BATLAS: Mid Norway plate reconstruction atlas with global and Atlantic perspectives. Norsk Geologiske Unders $\emptyset$ gelser, Trondheim, Norway, pp 18-39

68. Vogt PR, Crane K, Sundvor E, Max MD, Pfirman SL (1994) Methane-generated (?) pockmarks on young, thickly sedimented oceanic crust in the Arctic: Vestnesa Ridge, Fram Strait. Geol $22: 255-258$

69. Vorren TO, Hald M, Thomsen E (1984) Quaternary sediments and environments on the continental shelf of northern Norway. Mar Geol 57:229-257

70. Vorren TO, Laberg JS (1997) Trough mouth fans-palaeoclimate and ice-sheet monitors. Quat Sci Rev 16:865-881

71. Vorren TO, Laberg JS, Blaume F, Dowdeswell JA, Kenyon NH, Mienert J, Rumohr J, Werner F (1998) The Norwegian-Greenland sea continental margins: morphology and late Quaternary sedimentary processes and environment. Quat Sci Rev 17:273-302

72. Vorren TO, Lebesbye E, Andreassen K, Larsen KB (1989) Glacigenic sediments on a passive continental margin as exemplified by the Barents Sea. Mar Geol 85:251-272

73. Wilken M, Mienert J (2006) Submarine glacigenic debris flows, deep-sea channels and past ice-stream behaviour of the East Greenland continental margin. Quat Sci Rev 25:784-810 